\title{
Evaluation and comparison of antimicrobial efficacy of snail mucus of Egyptian Eremina desertorum and Helix aspersa with novel approach of their anti-inflammatory and wound healing potencies
}

Nessma A. EL-Zawawy ( $\square$ nesma.elzawawi@science.tanta.edu.eg )

Tanta University

Mahy M. Mona

Tanta University

Research Article

Keywords: Wound healing, Burn infection, Eremina desertorum, Helix aspersa

Posted Date: September 17th, 2021

DOI: https://doi.org/10.21203/rs.3.rs-899280/v1

License: (c) (i) This work is licensed under a Creative Commons Attribution 4.0 International License. Read Full License 


\section{Abstract}

Snail mucus is composed of bioactive compounds thought to have different biological properties for the treatment of some skin problems. Although Helix aspersa mucus is used in several cosmetic products, a detailed characterization of Eremina desertorum mucus composition and its biological activities is still missing. Mucus extracts (MEs) from $H$. aspersa and E. desertorum were prepared and tested for their antimicrobial, anti-inflammatory activities with their potencies in wound healing. Also, chemical characterization is done by GC-MS analysis. Results showed that ME of $E$. desertorum gave higher inhibitory activity against resistant strains related to burn wound infections compared to ME of $\mathrm{H}$. aspersa. Also, it revealed a significant anti-inflammatory activity. Moreover, we found that ME of E. desertorum lacked cytotoxicity and was able to significantly induce cell proliferation and migration through up-regulation expression of TGF $\beta 1$ and VEGF genes. Our results suggested that MEs of $E$. desertorum have higher biological effects compared to $H$. aspersa, which are attributable to antimicrobial, anti-inflammatory activities, cell proliferation and pave the way for further investigating its potential effect as a human therapeutic agent.

\section{Introduction}

Snails have a thick mucus coating that may aid in minimizing moisture loss, reducing friction which helps them to glide smoothly across dry surfaces, as well as protecting their bodies from physical harm ${ }^{1}$. Mucus secretions have a wide range of functions and biological activity ${ }^{2}$. Trail mucus is mostly composed of big, carbohydrate-rich polymers with a few tiny proteins ${ }^{3}$, which can relieve heartburn as mucus neutralizes stomach acidity and gastro esophageal reflux based on the role of snail mucus in mending ulcers and the role of human mucus in preventing or fighting acidity $^{4}$. Also, snails may produce a lot of mucin in their mucus secretion, which contains antibacterial proteins and gives them some resistance to infection by pathogens ${ }^{5}$. Moreover, several scientific studies have shown that bioactive compounds-derived from different mucus snails can be utilized in a wide range of therapies, such as creams to treat skin abrasions and scars, respiratory disorders, and heartburn ${ }^{6}$.

Eremina is very confined genus to many countries of North Africa region ${ }^{7}$ and considered as part of the natural ecosystem of Egypt ${ }^{8}$. Eremina desertorum is one of the common desert species occurred in many different locations along the Mediterranean region, between Alexandria till the border of Egypt with Libya ${ }^{9-11}$. Despite the spread of this species in Egypt, so far there is no study explaining the chemical composition or even proving the medical importance of the mucus extracted from it.

Burn wounds are one of the most important health issues worldwide, especially in the developing countries ${ }^{12}$.Microbial infections for burn wound patients are considered a huge problem as about $50-75 \%$ of mortality in hospitalized burn patients is due to microbial infections ${ }^{13}$. Moreover, lack of researches in Egypt on pathogenicity, resistance of microorganisms on burn wounds and statistical information makes the problem more complicated. Also, many studies on burn wound infections ignored host microbiota-associated pathogens ${ }^{14}$. Recently, Kopeck ${ }^{15}$ reported that the presence of some resistant microbial strains in burns could lower the efficiency of burn wound healing. Wound healing process is controlled by different cytokines and growth factors, such as transforming growth factorbeta 1 (TGF 1 ), and vascular endothelial growth factor (VEGF) ${ }^{16}$. TGF $\beta 1$ is created by cells such as T cells, platelets and macrophages, which releases neutrophils and fibroblasts to the site of damage at the inflammatory phase of wound healing ${ }^{17}$. Also, TGF $\beta 1$ helps in migration, growth, and motivation of fibroblasts ${ }^{18}$. Moreover, VEGF is created by several cells as well as endothelial cells, fibroblasts, platelets and neutrophils ${ }^{19}$. TGF $\beta 1$ and VEGF can suppress severe inflammation as inflammation is the response of living tissues to infected wound. The 
mechanism of anti-inflammatory agents depends on inhibiting the release of lysosomal constituents of activated neutrophils which can cause tissue damage and inflammation ${ }^{20}$.

Although the huge commercial diffusion of products from garden snail Helix aspersa mucus ${ }^{21-23}$, there have been no reports to discuss antimicrobial and anti-inflammatory activities of E. desertorum mucus. According to our knowledge, there are no studies on chemical composition of $E$. desertorum mucus related to its biological activities and its mechanisms in wound healing activity. Therefore, the aim of the present study is the first to identify the mucus chemical composition of the desert snail E. desertorum comparing to garden snail $H$. aspersa under Egyptian condition and explore it as a new antimicrobial, and anti-inflammatory approach against resistant pathogens of burn wound infections and its wound healing potency on human skin fibroblasts through expression of some growth factors genes.

\section{Results}

\section{Antimicrobial activities and MIC}

The present study is might be the first to investigate effect of MEs of $H$. aspersa and $E$. desertorum against MDR or PDR pathogenic microorganisms isolated from burn wound infections. Antimicrobial activities of both snails were tested against eight resistant pathogens as in Fig. 1. ME of E. desertorum showed higher significant inhibitory activity against tested strains with differences in their susceptibility than $H$. aspersa. While, both snails didn't show any inhibitory activity against KP-1 (Table 1). Fungal strains were found to be more susceptible strains to MCE of $E$. desertorum. The highest mean zones of inhibition ranged from $3 \pm 0.0$ to $55.2 \pm 0.1 \mathrm{~mm}$ and from $9.5 \pm 0.0$ to $30.5 \pm$ $0.06 \mathrm{~mm}$ against fungal and bacterial strains, respectively compared to DMSO (1\%) which didn't show any inhibition zone (Fig. 1). The values of minimum inhibitory concentrations (MIC) for each organism were shown in Table 1. MIC ranged between $(5$ and $20 \mu \mathrm{g} / \mathrm{ml}$ ) against bacterial strains, while MIC for fungal strains ranged between 7 and 32 $\mu \mathrm{g} / \mathrm{ml}$. 
Table 1

Antimicrobial activity of MEs of selected snails

\begin{tabular}{|c|c|c|c|c|c|c|c|c|c|}
\hline \multirow[t]{3}{*}{ Snails } & \multirow[t]{3}{*}{ Microorganisms } & \multicolumn{5}{|c|}{ Zone of inhibition (mm) } & \multirow{3}{*}{$\begin{array}{l}\text { MIC } \\
(\mu \mathrm{g} / \mathrm{ml})\end{array}$} & \multirow[t]{3}{*}{ DRPS } & \multirow{3}{*}{$\begin{array}{l}\text { Resistance } \\
\text { type }\end{array}$} \\
\hline & & \multicolumn{5}{|c|}{ Different concentrations $(\mu \mathrm{g} / \mathrm{ml})$} & & & \\
\hline & & 10 & 20 & 30 & 40 & 50 & & & \\
\hline 1 & $\begin{array}{l}\text { P. aeruginosa } \\
\text { (PA-9) }\end{array}$ & $\begin{array}{l}0.0 \pm \\
0.0\end{array}$ & $8 \pm 0.1$ & $\begin{array}{l}11.2 \\
\pm 0.1\end{array}$ & $\begin{array}{l}15.5 \\
\pm 0.06\end{array}$ & $\begin{array}{l}15.8 \pm \\
0.06\end{array}$ & 15 & $\begin{array}{l}\text { AX, } \\
\text { CAZ, } \\
\text { FEP, } \\
\text { ATM, } \\
\text { CRO, } \\
\text { IPM, } \\
\text { CIP, } \\
\text { SXT, }\end{array}$ & MDR \\
\hline 2 & & $\begin{array}{l}9.5 \pm \\
0.0\end{array}$ & $\begin{array}{l}13.9 \pm \\
0.1\end{array}$ & $\begin{array}{l}18.5 \pm \\
0.1\end{array}$ & $\begin{array}{l}22.8 \pm \\
0.06\end{array}$ & $\begin{array}{l}25.5 \pm \\
0.06\end{array}$ & 7 & & \\
\hline & & & & & & & & $\begin{array}{l}\mathrm{C}, \mathrm{CN} \text {, } \\
\text { TOB, } \\
\mathrm{K}, \mathrm{CT} \\
12\end{array}$ & \\
\hline 1 & E. coli & $\begin{array}{l}0.0 \pm \\
0.0\end{array}$ & $7 \pm 0.1$ & $\begin{array}{l}10 \\
\pm 0.1\end{array}$ & $\begin{array}{l}15.5 \\
+0.06\end{array}$ & $16.8 \pm$ & 20 & $\begin{array}{l}\mathrm{AX} \\
\mathrm{CA} 7\end{array}$ & MDR \\
\hline 2 & & $\begin{array}{l}10.5 \pm \\
0.0\end{array}$ & $\begin{array}{l}14.5 \pm \\
0.1\end{array}$ & $\begin{array}{l}20.5 \pm \\
0.1\end{array}$ & $\begin{array}{l}25.6 \pm \\
0.06\end{array}$ & $\begin{array}{l}30.5 \pm \\
0.06\end{array}$ & 5 & $\begin{array}{l}\text { CIP, } \\
\text { SXT, } \\
\text { C, } \\
\text { TOB, } \\
\text { K, CT } \\
20\end{array}$ & \\
\hline 1 & $\begin{array}{l}\text { K. pneumonia } \\
\text { (KP-1) }\end{array}$ & $\begin{array}{l}0.0 \pm \\
0.0\end{array}$ & $\begin{array}{l}0.0 \pm \\
0.0\end{array}$ & $\begin{array}{l}0.0 \pm \\
0.0\end{array}$ & $\begin{array}{l}0.0 \pm \\
0.0\end{array}$ & $\begin{array}{l}0.0 \pm \\
0.0\end{array}$ & ND & $\begin{array}{l}\text { PIP, } \\
\text { AMC, } \\
\text { TZP, } \\
\text { CTX, } \\
\text { NA, } \\
\text { AK, } \\
\text { VA, }\end{array}$ & PDR \\
\hline
\end{tabular}

Notes: Values are the mean of three replicates \pm SD. Means with the same letters in the same column showed the insignificant difference $(P \leq 0.05)$. Data obtained from our previous studies $[12,20,25,26]$.

1: H.aspersa; 2: E. desertorum; ND, Not detected; MIC, Minimum Inhibitory Concentration; DRPs, Drug-Resistance Patterns; MDR, Multi-Drug Resistance; PDR, Pan-Drug Resistance; AX, amoxicillin; CAZ, ceftazidime; FEP, cefepime; ATM, aztreonam, CRO, ceftriaxone; IMP, imipenem; CIP, ciprofloxacin; SXT, cotrimoxazole; C, chloramphenicol; CN, gentamicin; TOB, tobramycin; K, kanamycin; CT, colistin sulfate; PIP, piperacillin; AMC, amoxicillin/clavulanic acid; TZP, pipracillin/tazobactam; CTX, cefotaxime; CFP, cefoperazone; NA, nalidixic acid; AK, amikacin; TE, tetracycline; VA, vancomycin; AMB, amphotericin; FLC, fluconazole; ITC, itraconazole; CLT, clotrimazole; MIZ, miconazole; MCFG, micfungin; NYT, nystatin; TRB, terbinafine. 


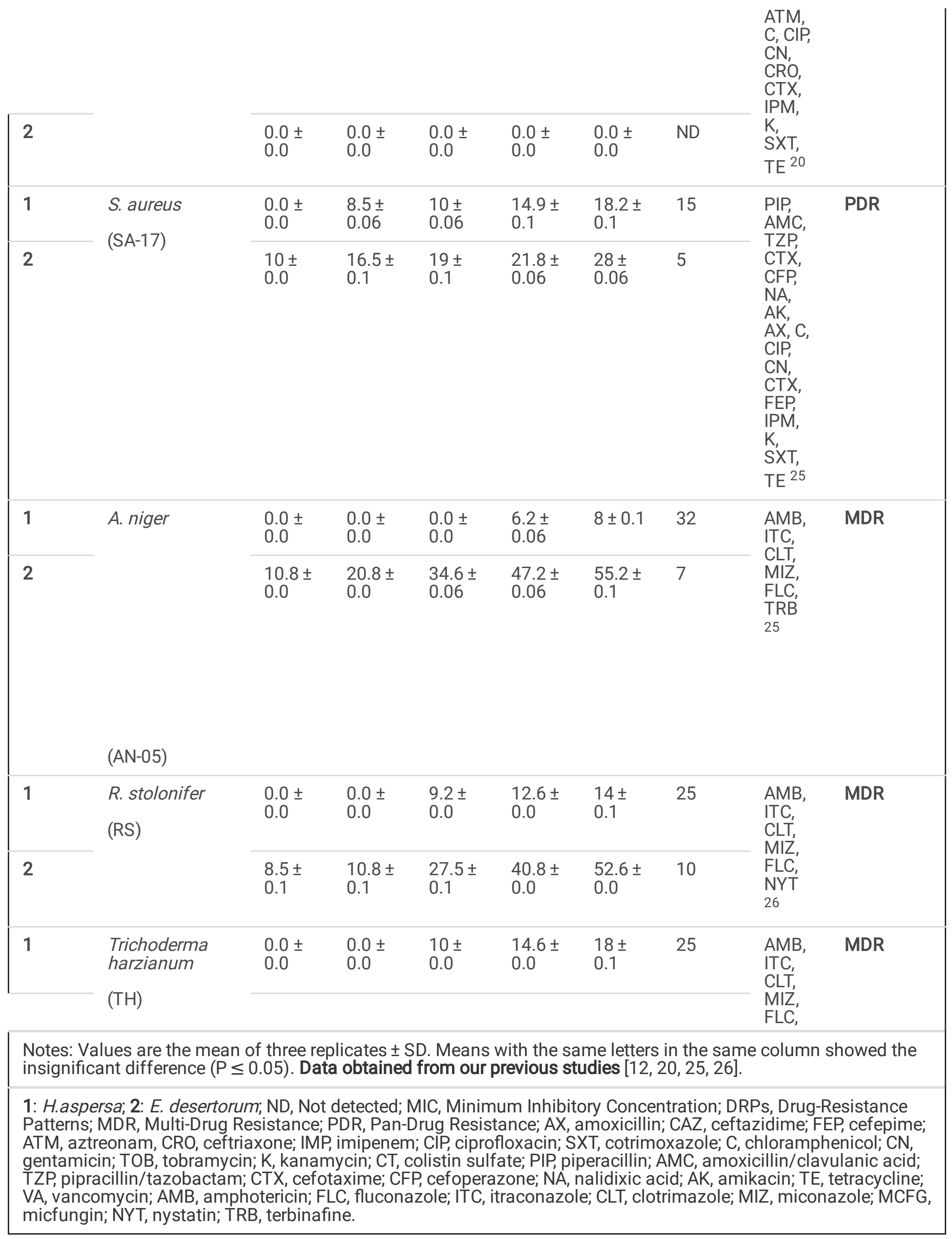




\begin{tabular}{|c|c|c|c|c|c|c|c|c|c|}
\hline 2 & & $8 \pm 0.1$ & $\begin{array}{l}10.2 \pm \\
0.1\end{array}$ & $\begin{array}{l}25.5 \pm \\
0.1\end{array}$ & $\begin{array}{l}38.8 \pm \\
0.0\end{array}$ & $\begin{array}{l}49.6 \pm \\
0.0\end{array}$ & 10 & $\begin{array}{l}\text { MCFG, } \\
\text { NYT } \\
26\end{array}$ & \\
\hline 1 & \multirow[t]{2}{*}{$\begin{array}{l}\text { C. albicans } \\
(\mathrm{CA}-11)\end{array}$} & $\begin{array}{l}0.0 \pm \\
0.0\end{array}$ & $3 \pm 0.0$ & $\begin{array}{l}8.6 \pm \\
0.06\end{array}$ & $\begin{array}{l}10.8 \pm \\
0.1\end{array}$ & $\begin{array}{l}13 \pm \\
0.06\end{array}$ & 20 & \multirow{2}{*}{$\begin{array}{l}\text { AMB, } \\
\text { ITC, } \\
\text { CLT, } \\
\text { MIZ, } \\
\text { FLC, } \\
\text { MCFG, } \\
\text { NYT, } \\
\text { TRB } \\
26\end{array}$} & \multirow[t]{2}{*}{ PDR } \\
\hline 2 & & $\begin{array}{l}7.8 \pm \\
0.0\end{array}$ & $\begin{array}{l}15.2 \pm \\
0.1\end{array}$ & $\begin{array}{l}26.8 \pm \\
0.1\end{array}$ & $\begin{array}{l}38.6 \pm \\
0.1\end{array}$ & $\begin{array}{l}49.2 \pm \\
0.06\end{array}$ & 12 & & \\
\hline \multirow[t]{2}{*}{ ANOVA } & P-value & $\begin{array}{l}<.0001 \\
0\end{array}$ & $\begin{array}{l}< \\
0.0001\end{array}$ & $<.0001$ & $<.0001$ & $<.0001$ & - & - & - \\
\hline & $\mathrm{F}$ & 34.15 & 64095 & 154.4 & 73302 & 36211 & - & - & - \\
\hline \multicolumn{10}{|c|}{$\begin{array}{l}\text { Notes: Values are the mean of three replicates } \pm S D \text {. Means with the same letters in the same column showed the } \\
\text { insignificant difference }(P \leq 0.05) \text {. Data obtained from our previous studies }[12,20,25,26] \text {. }\end{array}$} \\
\hline \multicolumn{10}{|c|}{$\begin{array}{l}\text { 1: H.aspersa; 2: E. desertorum; ND, Not detected; MIC, Minimum Inhibitory Concentration; DRPs, Drug-Resistance } \\
\text { Patterns; MDR, Multi-Drug Resistance; PDR, Pan-Drug Resistance; AX, amoxicillin; CAZ, ceftazidime; FEP, cefepime; } \\
\text { ATM, aztreonam, CRO, ceftriaxone; IMP, imipenem; CIP, ciprofloxacin; SXT, cotrimoxazole; C, chloramphenicol; CN, } \\
\text { gentamicin; TOB, tobramycin; K, kanamycin; CT, colistin sulfate; PIP, piperacillin; AMC, amoxicillin/clavulanic acid; } \\
\text { TZP, pipracillin/tazobactam; CTX, cefotaxime; CFP, cefoperazone; NA, nalidixic acid; AK, amikacin; TE, tetracycline; } \\
\text { VA, vancomy cin; AMB, amphotericin; FLC, fluconazole; ITC, itraconazole; CLT, clotrimazole; MIZ, miconazole; MCFG, } \\
\text { micfungin; NYT, nystatin; TRB, terbinafine. }\end{array}$} \\
\hline
\end{tabular}

Anti-inflammatory activities of MEs of $\mathrm{H}$. aspersa and $\mathrm{E}$. desertorum

The anti-inflammatory activities of MEs of both snails were determined through membrane stabilization, albumin denaturation, and proteinase inhibitory activity compared with aspirin as a refrence drug (Fig. 2). Both snails showed anti-inflammatory activities, while $E$. desertorum showed higher activity. E. desertorum showed highly significant stabilization toward human red blood cells membrane. Also, the percentage inhibition of albumin denaturation for $E$. desertorum at concentration $2000 \mu \mathrm{g} / \mathrm{ml}$ was higher than that of aspirin at the same concentration with inhibition $92.8 \%$ and $85.3 \%$, respectively. Moreover, a significant increase in inhibiting proteinase activity was highly similar to that of aspirin with inhibition of $89.9 \%$ and $89.2 \%$, respectively at concentration of $2000 \mu \mathrm{g} / \mathrm{ml}$.

\section{Lack of cytotoxicity of MEs of $\mathrm{H}$. aspersa and $\mathrm{E}$. desertorum}

To evaluate the biological effects of MEs of both snails, human skin fibroblasts (HSF) cells were treated in vitro with different concentrations $(0.03-300 \mu \mathrm{g} / \mathrm{ml})$ of both snails, to show their effect on normal cell viability and morphology. Figure (3 A, B) showed lack of cytotoxicity of both snails as the percentage viability of HSF cells at the highest treated concentration of MEs of $H$. aspersa and E. desertorum were observed to be $93 \%$ and $75.8 \%$, respectively compared to untreated samples and DMSO(1\%) and (10\%) as different controls. The concentrations of MEs of both snails used for treatment and their corresponding percentage cell viability showed $\mathrm{IC}_{50}>300 \mu \mathrm{g} / \mathrm{ml}$ in both snails which confirmed the disappearance of any toxic effect of treated concentration.

\section{Induction of MEs of both snails to cell migration and wound repair}

Beside the cell viability, cell migration and proliferation properties of both snails were determined by the scratch wound assay. As shown in Fig. 4A, both snails improved wound healing process compared to untreated cells as ME of E. desertorum induced the migration of HSF cells resulting in complete wound closure after $48 \mathrm{hrs}$. faster than ME of 
$\mathrm{H}$. aspersa. Figure 4B indicated that E. desertorum, at $300 \mu \mathrm{g} / \mathrm{ml}$, closed the gap created by the scratch by $99.2 \%$ after $48 \mathrm{hrs}$. While, in untreated cells, $55.1 \%$ of the gap was closed at $48 \mathrm{hrs}$.

\section{Upregulation of TGF $\beta 1$ and VEGF genes expression}

The present investigation determined changes in the expression of TGF $\beta 1$ and VEGF genes by realtimePCR in HSF cells with MEs of both snails at 48hrs after treatment. To determine possible molecular mechanism of the induction of MEs of both snails to wound repair and healing, we tested the expression level of TGF 11 and VEGF genes. Expression of TGF $\beta 1$ gene treated by MEs of $H$. aspersa and $E$. desertorum was significantly upregulated by 5-fold, and 7.5-fold, respectively, when compared to the control (Fig. 5). Also, expression of VEGF gene was significantly upregulated by 2fold, and 3.5-fold when treated with MEs of $H$. aspersa and $E$. desertorum, respectively.

\section{Chemical analysis of MEs of both snails using GC-MS}

Chemical constituents, molecular weight and peak area of each component for MEs of both snails were listed in Tables $(2,3)$. Our results indicated that the major compounds in ME of E. desertorum were 3H-1,2,4-triazole-3thione,4,5-dihydro-4,5-diphenyl followed by phthalic acid, 7-bromoheptyl ethyl ester and methyl 1,2-benzisothiazole-3acetate. While in ME of $H$. aspersa, the major compounds were Thiophene, 3-(decyloxy)tetrahydro-, 1,1-dioxide followed by 4-(Nonafluoro-tert-butyl) nitrobenzene. So, further study will be done for the isolation and the purification of these active compounds with a comprehensive toxicological analysis to determine its safety as it is beyond the scope of this paper.

\section{Discussion}

Based on previous investigations, antimicrobial activities of mucus from mollusks including snails and slugs have never been suggested extensively ${ }^{24}$. According to several reports, antimicrobial activity depends on snail species, extraction method, and the resistance of the tested organism ${ }^{25}$. In the present study, ME of E. desertorum was the most effective snail against the most selected resistant strains with a strong inhibitory activity. These results were similar to Lopez ${ }^{26}$ who evaluated the antimicrobial activity of the crude extract of marine snail $C$. muricatus. Although, there are few reports on potent antimicrobial activities of extracts from $H$. aspersa, our study is considered the first to explore antimicrobial activities of $E$. desertorum compared to $H$. aspersa against resistant pathogens related to burn wound infection.

ME of E. desertorum showed a significant anti-inflammatory activity through membrane stabilization, albumin denaturation, and proteinase inhibitory activity compared with commercially aspirin. It might be the first study to discuss the in vitro anti-inflammatory activity of this snail. Therefore, we suggest it as a new alternative agent with a potent anti-inflammatory activity in the treatment of burn wounds infections. Hence, ME of $E$. desertorum treatment was further conducted in order to evaluate the efficacy of this snail in curing the burn wound infections.

Moreover, ME of $E$. desertorum accelerates wound healing by inducing the migration of fibroblasts with enhancing the expression of wound healing related gene (TGF $\beta 1$ and VEGF). This is in agreement with Coppe ${ }^{27}$ who demonstrated that methanolic extract of $C$. molmoland ethanolic extract of henna significantly improved the expression of TGF $\beta 1$ and VEGF genes at $48 \mathrm{hrs}$. after treatment of normal mouse fibroblast cells. However, there are some reports on wound healing activity of mucus of different snails ${ }^{28}$, there are no reports on effect of this snail on expression of wound healing related genes.

It was necessary as a next step to check the chemical composition of bioactive compounds in both snails. The differences in their biological activities may be due to differences in the active compounds that present in both snails. 
GC-MS analysis indicated that the chemical constituents of the most promising ME of E. desertorum snailhad 3 major different peaks compared to $H$. aspersa; which are $3 \mathrm{H}-1,2,4$-triazole-3-thione,4,5-dihydro-4,5-diphenyl followed by phthalic acid, 7-bromoheptyl ethyl ester and methyl 1,2-benzisothiazole-3-acetate. Similarly, the first compound showed a potent antibacterial activity ${ }^{29}$. The second component was reported to have several biological activities ${ }^{30}$. In addition, the third one showed a strong antimicrobial activity ${ }^{31}$. While in Egyptian $H$. aspersa, there were another two major compounds; Thiophene, 3-(decyloxy)tetrahydro-, 1,1-dioxide followed by 4-(Nonafluoro-tert-butyl) nitrobenzene which had different biological activities ${ }^{32,33}$. This variation in mucus composition could be attributed to species differences, as well as mechanical factors such as temperature, humidity, light intensity, soil conditions, and food supply. These data agreements with Meikle ${ }^{34}$ who found substantial differences between the mucus of six coral species. Also, Sallam ${ }^{35}$ observed several chemical variations in the composition of three common Egyptian land snails, Eobania vermiculata, Theba pisana and Monacha obstructa mucus. Between the two species in this study, it should not be surprising that different forms of mucus have different compositions and different mechanical properties according to their environmental living condition. These environmental conditions also affect the physical properties of the two snail species in terms of color and viscosity. The garden snail Helix aspersa was colorless and less viscosity comparing with mucus dessert snail Eremina desertorum with slightly cloudy-white with high viscous. Dessert snail's high viscosity acted as a barrier, preventing moisture loss and safeguarding the snail from bacterial infection ${ }^{1,36}$. Finally, these results suggest that $E$. desertorum snail is a mixture of several compounds, and each component might contribute to its biological activity than if they acted alone. Therefore, the current study suggested that $\mathrm{ME}$ of $E$. desertorum snail is a potential source of natural components that possessed antimicrobial and antiinflammatory properties that may be used for the treatment of burn wound infections. Also, it can induce wound healing by improving expression of growth factors genes. However, so far, there is no available toxicological data on human regarding the $E$. desertorum snail; therefore, further assessment should be performed to define the safety doses of this novel snail for human use.

\section{Conclusion}

This study has evidenced the efficacy of ME of E. desertorum snail as a new antimicrobial and anti-inflammatory agent in burn wound infections, highlighting its efficiency in wound healing for future usage in topical technology. Moreover, in vivo and human studies need to be performed further to confirm the snail biological properties.

\section{Material And Methods}

\section{Snail collection and mucus extraction:}

Thirty adult of garden snail Helix aspersa and desert snail Eremina desertorum were collected from Foah region, Kafr El-sheikh, Egypt $\left(31^{\circ} 06^{\prime} 42^{\prime \prime} \mathrm{N} 30^{\circ} 56^{\prime} 45^{\prime \prime} \mathrm{E}\right)$ and El Alamein, Western Coast, Egypt (30 $\left.50^{\prime} \mathrm{N} 28^{\circ} 57^{\prime} \mathrm{E}\right)$, respectively. The samples were identified according to Schileyko ${ }^{37}$ as reported in supplementary data (Fig S1). Each species of snail was housed in two separately plastic boxes, each with 15 snails. To keep the plastic boxes damp, they were sprayed with water every day. Then snails were transferred individually packaged in plastic containers and stored. To avoid infection, go 3 days without eating.

Snails were manually stimulated at the pedal glands in their foot. Each individual's mucus sample is collected and then pooled for each species. About $100 \mathrm{ml}$ of crude extract from 25 snails of each species was collected. The harvested mucus was filtered). Mucus was than sterilized by filtering through $0.45-\mu \mathrm{m}$ membrane then stored at - 
$80^{\circ} \mathrm{C}$. In order to obtain only the dry part, Mucus samples were lyophilized overnight to obtain a solid powder that was used for the biological characterization.

Microbiological characterization. Bacterial contamination was tested by plating $100 \mu$ l of mucus extracts (MEs) of both snails on Tryptic Soy agar (TSA) medium (Biomerieux, Italy). Colonies number were counted after incubation for 24-48 hrs. at $37^{\circ} \mathrm{C}$ and expressed as colony forming unit (CFU). Also, fungal and yeast contamination was evaluated by plating $100 \mu \mathrm{l}$ of MEs of both specimens on Sabouraud medium plates (Biomerieux, Italy). Fungal growth was noticed after incubation for $5-7$ days at $30^{\circ} \mathrm{C}^{23}$. Microbiological evaluation of MEs of selected strains is reported in supplementary data (Table S1), which confirmed the sterilization of MEs of both snails by the absence of fungal and bacterial contaminations without addition of any preservative.

\section{Microbial strains}

Eight clinical resistant bacterial and fungal strains used in this study were isolated previously from burn wound infections. The pathogenic bacteria were $P$. aeruginosa $(\mathrm{PA}-9)^{12}$, E. coli (EC-3) ${ }^{20}, K$. pneumonia $(\mathrm{KP}-1)$ and $S$. aureus $(\mathrm{SA}-17)^{20,38}$. While, pathogenic fungal strains were $A$. niger (AN-05), R. stolonifer (RS), Trichoderma harzianum (TH). and $C$. albicans $(\mathrm{CA}-11)^{38,39}$. All isolates were identified as MDR or PDR strains as described previously in our studies ${ }^{12,38,39}$ and stored at $-70^{\circ} \mathrm{C}$. Active cultures for further experiments were prepared by transferring a loop full of culture from frozen glycerol stock cultures of each strain to test tubes of Mueller-Hinton broth (MHB) (Merck, Darmstadt, Germany) for bacteria, and Sabouraud Dextrose (SD) broth for fungi, and were incubated for 24-48 hrs. at $37^{\circ} \mathrm{C}$.

\section{Antimicrobial activity assay and Minimum Inhibitory Concentration (MIC)}

Antimicrobial activities of MEs from both snails were assessed against the eight selected strains by agar well diffusion method as detailed in El- Zawawy ${ }^{40}$.The agar plates were swabbed with $100 \mu$ l broth culture of selected strains. Wells were made in agar plates using a sterile cork borer of $5 \mathrm{~mm}$. MEs were dissolved in $1 \%$ pure dimethyl sulfoxide (DMSO; Sigma-Aldrich, St. Louis, Missouri, USA) to a final concentration of $100 \mu \mathrm{g} / \mathrm{ml}$. Twenty microliters of various concentrations $(10,20,30,40,50 \mu \mathrm{g} / \mathrm{ml})$ were added to each well. DMSO (1\%) was used as a negative control. The minimum inhibitory concentration (MIC) was determined by micro dilution method ${ }^{41}$. The growth was observed and the optical density was read at $595 \mathrm{~nm}$ spectrophotometrically. MIC was determined by the lowest concentration of sample that inhibited the development of turbidity.

\section{Anti-inflammatory activity}

The anti-inflammatory activities of MEs from both snails were determined in vitro by three experiments as described in our previous studies ${ }^{12,42}$ in details; membrane stabilization of human red blood cells, albumin denaturation and proteinase inhibitory activity. Different concentrations $(100,200,300,400,500,1000$ and $2000 \mu \mathrm{g} / \mathrm{ml})$ of both snails were prepared and compared with DMSO (1\%) as a negative control and aspirin (Bayer, Leverkusen, Germany) as a reference drug.

Cell culture

Human Skin Fibroblast (HSF) cell line employed in this study was obtained from Nawah Scientific Inc., (Mokatam, Cairo, Egypt). Cells were maintained in DMEM media supplemented with $100 \mathrm{mg} / \mathrm{ml}$ of streptomycin, 100 units $/ \mathrm{ml}$ of penicillin and $10 \%$ of heat-inactivated fetal bovine serum in humidified, $5 \%(\mathrm{v} / \mathrm{v}) \mathrm{CO}_{2}$ atmosphere at $37^{\circ} \mathrm{C}$. Cells were 
counted by hemocytometer and viability was calculated to seed the cells at appropriate densities, to perform the assays.

\section{Cell viability and Cytotoxicity studies}

The cytotoxicity of MEs of both snails on HSF cells was evaluated by SRB assay ${ }^{43}$. Briefly, HSF cells with initial density ( $5 \times 10^{3}$ cells) were seeded in 96-well plate and incubated with $100 \mu$ l of DMEM media for $24 \mathrm{~h}$. Cells were then treated with another aliquot of $100 \mu \mathrm{l}$ media containing MEs of both snails separately at various concentrations $(0.03$, $0.3,3,30,300 \mu \mathrm{g} / \mathrm{ml}$ ). After $72 \mathrm{~h}$ of treatment exposure, cells were fixed by replacing media with $150 \mu \mathrm{l}$ of $10 \%$ TCA and incubated at $4^{\circ} \mathrm{C}$ for $1 \mathrm{~h}$. The TCA solution was removed, and the cells were washed 5 times with distilled water. Aliquots of $70 \mu \mathrm{l} \mathrm{SRB}$ solution $(0.4 \% \mathrm{w} / \mathrm{v})$ were added and incubated in a dark place at room temperature for $10 \mathrm{~min}$. Plates were washed 3 times with 1\% acetic acid and allowed to air-dry overnight. Then, $150 \mu$ of Tris (10 mM) was added to dissolve protein-bound SRB stain; the absorbance was measured at $540 \mathrm{~nm}$ using a BMG LABTECH®FLUOstar Omega microplate reader (Ortenberg, Germany). The cells treated with DMEM alone, 1\% DMSO and 10\% DMSO were considered as negative, vehicle and positive controls, respectively ${ }^{23}$.

\section{Scratch assay and assessment of cell migration}

The wound healing properties of MEs of both snails were tested on HSF cells scratch assay ${ }^{44}$. Briefly, cells were seeded at density of $3 \times 10^{5} \mathrm{cells} /$ well in 6-well plate and were cultured overnight. After $24 \mathrm{hrs}$. medium was removed and a linear scratch in the middle of the well was done using a p200 tip. Then $400 \mu \mathrm{l}$ of selected snails with a concentration of $300 \mu \mathrm{g} / \mathrm{ml}$ or media (control) were added to each well. Scratch repair and cell migration were observed in the images taken by inverted microscope, equipped with digital camera. The experiments were performed in triplicate. The width of the scratch and wound closure at different time intervals $(0,24$ and $48 \mathrm{hrs}$.) was analyzed by MII Image View software version 3.7.

\section{Real time PCR (qRT-PCR) expression analysis.}

Effect of MEs of selected snails on the expression of transforming growth factorbeta 1 gene TGF $\beta 1$ and vascular endothelial growth factor gene (VEGF), was evaluated by qRT-PCR. Hot phenol/chloroform extraction method ${ }^{45}$ was used in extraction of total RNA. The obtained CDNA was then used for realtime polymerase chain reaction (PCR) using master SYBR Green I (Takara Bio, Japan) on ABI 7900HT. Realtime PCR was executed at $95^{\circ} \mathrm{C}$ for $10 \mathrm{~s}, 62^{\circ} \mathrm{C}$ for $15 \mathrm{~s}$, and $72^{\circ} \mathrm{C}$ for $8 \mathrm{~s}$ using the primers for the normalizing GAPDH gene against the Tgf $\beta 1$ and VegfA target genes. Primers were designed by Gen-Script according to the cDNA sequences of mouse TGF $\beta 1$ and VEGF and GAPDH in Gene Bank as shown in S2. Table 2. Realtime PCR was performed in triplicate for every cDNA. Expression in fibroblast cells was treated with each extract at 24 and 48 hrs after treatment were compared with the control (nontreated cells) after normalization with GAPDH. We used relative gene expression, to identifying the increase or decrease of a transcript of target gene in treated sample versus control sample via normalizing with a housekeeping gene. To determine the difference of the gene expression between groups, the data were analyzed using the Relative Expression Software Tool (REST; version 2009). 
Table 2

Chemical Constituents ME of E. desertorum using GC-MS

\begin{tabular}{|c|c|c|c|c|c|}
\hline Peak & Name of Compound & $\begin{array}{l}\text { Molecular } \\
\text { Formula }\end{array}$ & $\begin{array}{l}\text { Molecular } \\
\text { Weight } \\
\text { g/mol }\end{array}$ & $\begin{array}{l}\text { Retention } \\
\text { time } \\
\text { (min) }\end{array}$ & $\begin{array}{l}\text { Peak } \\
\text { Area } \\
(\%)\end{array}$ \\
\hline 1 & Bis(trimethylsiloxy)methylsilane & $\mathrm{C}_{7} \mathrm{H}_{21} \mathrm{O}_{2} \mathrm{Si}_{3}$ & 221.50 & 5.376 & 1.11 \\
\hline 2 & 4-Trimethylsilyl-9,9-dimethyl-9-silafluorene & $\mathrm{C}_{17} \mathrm{H}_{22} \mathrm{Si}_{2}$ & 282.5 & 5.620 & 1.72 \\
\hline 3 & $\begin{array}{l}\text { 3,6,9,12,15,18-Hexaoxanonadecan-1-ol, TMS } \\
\text { derivative }\end{array}$ & $\mathrm{C}_{16} \mathrm{H}_{36} \mathrm{O}_{7} \mathrm{Si}$ & 368.54 & 5.829 & 0.57 \\
\hline 4 & Decamethyl cyclo penta siloxane & $\mathrm{C}_{10} \mathrm{H}_{30} \mathrm{O}_{5} \mathrm{Si}_{5}$ & 370.77 & 5.984 & 2.47 \\
\hline 5 & Methyl 1,2-benzisothiazole-3-acetate & $\mathrm{C}_{10} \mathrm{H}_{9} \mathrm{NO}_{2} \mathrm{~S}$ & 207.25 & 7.507 & 5.39 \\
\hline 6 & 4-(Nonafluoro-tert-butyl) nitrobenzene & $\mathrm{C}_{10} \mathrm{H}_{4} \mathrm{~F}_{9} \mathrm{NO}_{2}$ & 341.13 & 7.613 & 2.07 \\
\hline 7 & $\begin{array}{l}\text { Benzeneacetaldehyde, .alpha.- } \\
\text { (methoxymethylene)-4-nitro- }\end{array}$ & $\mathrm{C}_{10} \mathrm{H}_{9} \mathrm{NO}_{4}$ & 207.18 & 7.937 & 1.54 \\
\hline 8 & Ehoxytris(trimethylsiloxy)silane & $\mathrm{C}_{11} \mathrm{H}_{32} \mathrm{O}_{4} \mathrm{Si}_{4}$ & 340.71 & 7.978 & 0.63 \\
\hline 9 & $\begin{array}{l}\text { 1-(3,6,6-Trimethyl-1,6,7,7a- } \\
\text { tetrahydrocyclopenta[c]pyran-1-yl)ethanone }\end{array}$ & $\mathrm{C}_{13} \mathrm{H}_{18} \mathrm{O}_{2}$ & 206.28 & 8.025 & 1.73 \\
\hline 10 & 5H-Dibenzo[a,d]cyclohepten-5-amine & $\mathrm{C}_{15} \mathrm{H}_{13} \mathrm{~N}$ & 207.27 & 8.055 & 2.05 \\
\hline 11 & Methyl 1,2-benzisothiazole-3-acetate & $\mathrm{C}_{10} \mathrm{H}_{9} \mathrm{NO}_{2} \mathrm{~S}$ & 207.25 & 8.989 & 1.23 \\
\hline 12 & $\begin{array}{l}\text { Methyl 2-oxo-1,2,5,6,7,8-hexahydroquinoline-3- } \\
\text { carboxylate }\end{array}$ & $\mathrm{C}_{11} \mathrm{H}_{13} \mathrm{NO}_{3}$ & 207.23 & 9.084 & 1.97 \\
\hline 13 & Phthalic acid, 7-bromoheptyl ethyl ester & $\mathrm{C}_{17} \mathrm{H}_{23} \mathrm{BrO}_{4}$ & 371.3 & 9.148 & 7.29 \\
\hline 14 & Diethyl Phthalate & $\mathrm{C}_{6} \mathrm{H}_{4}\left(\mathrm{COOC}_{2} \mathrm{H}_{5}\right)_{2}$ & 222.24 & 9.250 & 3.26 \\
\hline 15 & $\begin{array}{l}\text { Prop-2-enoic acid, 2-cyano-3-(3-methyl-2-thienyl)-, } \\
\text { methyl ester }\end{array}$ & $\mathrm{C}_{10} \mathrm{H}_{9} \mathrm{NO}_{2} \mathrm{~S}$ & 207.25 & 9.302 & 1.44 \\
\hline 16 & Isophthalic acid, 2-methoxyethyl isobutyl ester & $\mathrm{C}_{15} \mathrm{H}_{20} \mathrm{O}_{5}$ & 280.32 & 9.369 & 1.64 \\
\hline 17 & $\begin{array}{l}\text { Prop-2-enoic acid, 2-cyano-3-(3-methyl-2-thienyl)-, } \\
\text { methyl ester }\end{array}$ & $\mathrm{C}_{10} \mathrm{H}_{9} \mathrm{NO}_{2} \mathrm{~S}$ & 207.25 & 9.467 & 1.24 \\
\hline 18 & $\begin{array}{l}\text { 7,7,9,9,11,11-Hexamethyl-3,6,8,10,12,15-hexaoxa- } \\
\text { 7,9,11-trisilaheptadecane }\end{array}$ & $\mathrm{C}_{14} \mathrm{H}_{36} \mathrm{O}_{6} \mathrm{Si}_{3}$ & 384.69 & 9.904 & 2.72 \\
\hline 19 & Silicic acid, diethyl bis(trimethylsilyl) ester & $\mathrm{C}_{10} \mathrm{H}_{28} \mathrm{O}_{4} \mathrm{Si}_{3}$ & 296.58 & 10.004 & 1.63 \\
\hline 20 & Benzene, [1-(3-butenylthio)-2-nitroethyl]- & $\mathrm{C}_{12} \mathrm{H}_{15} \mathrm{NO}_{2} \mathrm{~S}$ & 237.32 & 10.506 & 2.31 \\
\hline 21 & $\begin{array}{l}\text { Benzothiophene-3-carboxylic acid,4,5,6,7- } \\
\text { tetrahydro-2-amino-6-ethyl -, ethyl ester }\end{array}$ & $\mathrm{C}_{13} \mathrm{H}_{19} \mathrm{NO}_{2} \mathrm{~S}$ & 253.36 & 11.107 & 3.58 \\
\hline 22 & Propanephosphonic acid, bis(trimethylsilyl) ester & $\mathrm{C}_{9} \mathrm{H}_{25} \mathrm{O}_{3} \mathrm{PSi}_{2}$ & 268.44 & 11.291 & 3.68 \\
\hline 23 & 3H-1,2,4-triazole-3-thione, 4,5-dihydro-4,5-diphenyl- & $\mathrm{C}_{14} \mathrm{H}_{11} \mathrm{~N}_{3} \mathrm{~S}$ & 253.32 & 11.483 & 6.07 \\
\hline
\end{tabular}




\begin{tabular}{|c|c|c|c|c|c|}
\hline Peak & Name of Compound & $\begin{array}{l}\text { Molecular } \\
\text { Formula }\end{array}$ & $\begin{array}{l}\text { Molecular } \\
\text { Weight } \\
\text { g/mol }\end{array}$ & $\begin{array}{l}\text { Retention } \\
\text { time } \\
\text { (min) }\end{array}$ & $\begin{array}{l}\text { Peak } \\
\text { Area } \\
\text { (\%) }\end{array}$ \\
\hline 24 & Cyclotrisiloxane, hexamethyl- & $\mathrm{C}_{6} \mathrm{H}_{18} \mathrm{O}_{3} \mathrm{Si}_{3}$ & 222.46 & 11.686 & 0.95 \\
\hline 25 & 1,2-Bis(trimethylsilyl)benzene & $\mathrm{C}_{12} \mathrm{H}_{22} \mathrm{Si}_{2}$ & 222.47 & 11.712 & 0.34 \\
\hline 26 & 6-Methyl-2-(3-nitrophenyl)imidazo[1,2 a]pyridine & $\mathrm{C}_{14} \mathrm{H}_{11} \mathrm{~N}_{3} \mathrm{O}_{2}$ & 253.26 & 12.052 & 1.83 \\
\hline 27 & Phthalic acid, 7-bromoheptyl ethyl ester & $\mathrm{C}_{17} \mathrm{H}_{23} \mathrm{BrO}_{4}$ & 371.3 & 12.130 & 2.84 \\
\hline 28 & Diethyl Phthalate & $\mathrm{C}_{12} \mathrm{H}_{14} \mathrm{O}_{4}$ & 222.24 & 12.163 & 4.26 \\
\hline 29 & $\begin{array}{l}\text { Benzothiophene-3-carboxylic acid, 4,5,6,7- } \\
\text { tetrahydro-2-amino-6-ethyl - , ethyl ester }\end{array}$ & $\mathrm{C}_{13} \mathrm{H}_{19} \mathrm{NO}_{2} \mathrm{~S}$ & 353.36 & 12.267 & 4.12 \\
\hline 30 & 6Methyl2(3nitrophenyl)imidazo[1,2-a]pyridine & $\mathrm{C}_{14} \mathrm{H}_{11} \mathrm{~N}_{3} \mathrm{O}_{2}$ & 253.26 & 12.561 & 1.13 \\
\hline 31 & $\begin{array}{l}\text { Methyl 6,6,8,8,10,10-hexamethyl-3-oxo-2,5,7,9,11- } \\
\text { pentaoxa-6,8,10-trisilatridecan-13-oate }\end{array}$ & $\mathrm{C}_{12} \mathrm{H}_{28} \mathrm{O}_{8} \mathrm{Si}_{3}$ & 348.60 & 12.693 & 1.58 \\
\hline 32 & 1,1,1,3,5,5,5-Heptamethyltrisiloxane & $\mathrm{C}_{7} \mathrm{H}_{21} \mathrm{O}_{2} \mathrm{Si}_{3}$ & 221.50 & 13.830 & 0.45 \\
\hline 33 & $\begin{array}{l}\text { Cyclohexa-2,5-diene-1,4-dione, 2-methyl-5-(4- } \\
\text { morpholinyl)- }\end{array}$ & $\mathrm{C}_{11} \mathrm{H}_{13} \mathrm{NO}_{3}$ & 207.23 & 13.848 & 0.19 \\
\hline 34 & Methyltris(trimethylsiloxy)silane & $\mathrm{C}_{10} \mathrm{H}_{30} \mathrm{O}_{3} \mathrm{Si}_{4}$ & 310.68 & 14.040 & 0.75 \\
\hline 35 & $\begin{array}{l}\text { 9H-Fluorene-4-carboxylic acid, 9-oxo-, (2,6- } \\
\text { dimethylphenyl)amide }\end{array}$ & $\mathrm{C}_{22} \mathrm{H}_{17} \mathrm{NO}_{2}$ & 327.4 & 14.270 & 0.84 \\
\hline 36 & $\begin{array}{l}\text { Benzothiophene-3-carboxylic acid, 4,5,6,7- } \\
\text { tetrahydro - 2-amino-6-ethyl -, ethyl ester }\end{array}$ & $\mathrm{C}_{13} \mathrm{H}_{19} \mathrm{NO}_{2} \mathrm{~S}$ & 353.36 & 15.820 & 2.10 \\
\hline
\end{tabular}


Table 3

Chemical Constituents ME of $H$. aspersa using GC-MS

\begin{tabular}{|c|c|c|c|c|c|}
\hline Peak & Name of Compound & $\begin{array}{l}\text { Molecular } \\
\text { Formula }\end{array}$ & $\begin{array}{l}\text { Molecular } \\
\text { Weight } \mathrm{g} / \mathrm{mol}\end{array}$ & $\begin{array}{l}\text { Retention } \\
\text { time } \\
\text { (min) }\end{array}$ & $\begin{array}{l}\text { Peak } \\
\text { Area } \\
(\%)\end{array}$ \\
\hline 1 & (Z)-2-Heptene & $\mathrm{C}_{7} \mathrm{H}_{14}$ & 98.1861 & 5.163 & 1.11 \\
\hline 2 & 4H-Thiopyran-4-one, tetrahydro-, 1,1-dioxide & $\mathrm{C}_{5} \mathrm{H}_{8} \mathrm{O}_{3} \mathrm{~S}$ & 148.18 & 5.186 & 2.12 \\
\hline 3 & $\begin{array}{l}\text { Thiophene, 3-(decyloxy)tetrahydro-, 1,1- } \\
\text { dioxide }\end{array}$ & $\mathrm{C}_{14} \mathrm{H}_{28} \mathrm{O}_{3} \mathrm{~S}$ & 276.44 & 5.245 & 4.85 \\
\hline 4 & $\begin{array}{l}\text { Thiophene, 3-(decyloxy)tetrahydro-, 1,1- } \\
\text { dioxide }\end{array}$ & $\mathrm{C}_{14} \mathrm{H}_{28} \mathrm{O}_{3} \mathrm{~S}$ & 276.44 & 5.300 & 6.12 \\
\hline 5 & 2-Ethylacridine & $\mathrm{C}_{15} \mathrm{H}_{13} \mathrm{~N}$ & 207.27 & 5.369 & 1.73 \\
\hline 6 & Auramine & $\mathrm{C}_{17} \mathrm{H}_{21} \mathrm{~N}_{3}$ & 267.37 & 5.621 & 2.18 \\
\hline 7 & Methyltris(trimethylsiloxy)silane & $\mathrm{C}_{10} \mathrm{H}_{30} \mathrm{O}_{3} \mathrm{Si}_{4}$ & 310.68 & 5.854 & 3.00 \\
\hline 8 & $\begin{array}{l}\mathrm{N}-(\text { Trifluoroacetyl)-N,O,O',O"-tet } \\
\text { rakis(trimethylsilyl)norepinephrin }\end{array}$ & $\mathrm{C}_{22} \mathrm{H}_{42} \mathrm{~F}_{3} \mathrm{NO}_{4} \mathrm{Si}_{4}$ & 553.9 & 5.985 & 3.07 \\
\hline 9 & 4-(Nonafluoro-tert-butyl) nitrobenzene & C10H4F9NO2 & 341.13 & 7.526 & 4.86 \\
\hline 10 & Cyclohexasiloxane, dodecamethyl- & $\mathrm{C}_{12} \mathrm{H}_{36} \mathrm{O}_{6} \mathrm{Si}_{6}$ & 444.92 & 7.614 & 3.57 \\
\hline 11 & $\begin{array}{l}\text { 3-Isopropoxy-1,1,1,5,5,5-hexamethy I-3- } \\
\text { (trimethylsiloxy)trisiloxane }\end{array}$ & $\mathrm{C}_{12} \mathrm{H}_{34} \mathrm{O}_{4} \mathrm{Si}_{4}$ & 354.74 & 8.857 & 4.14 \\
\hline 12 & Mercaptoethanol, 2TMS derivative & $\mathrm{C}_{8} \mathrm{H}_{22} \mathrm{OSSi}_{2}$ & 222.50 & 9.916 & 1.95 \\
\hline 13 & $\begin{array}{l}\text { Octasiloxane, } \\
\text { 1,1,3,3,5,5,7,7,9,9,11,11,13,13,15,15- } \\
\text { hexadecamethyl- }\end{array}$ & $\mathrm{C}_{16} \mathrm{H}_{48} \mathrm{O}_{7} \mathrm{Si}_{8}$ & 577.2 & 10.011 & 2.13 \\
\hline 14 & N-(2-Acetylcyclopentylidene)cyclohexylamine & $\mathrm{C} 13 \mathrm{H} 21 \mathrm{NO}$ & 207.31 & 10.507 & 2.16 \\
\hline 15 & 6-Chloro-4-phenyl-2-propylquinolin & $\mathrm{C}_{18} \mathrm{H}_{16} \mathrm{CIN}$ & 281.8 & 5.163 & 1.11 \\
\hline
\end{tabular}

\section{Gas chromatography-mass spectrometer (GC-MS) analysis}

MCEs of both snails were investigated for their phytoconstituents using GC-MS (Trace GC Ultra, USA), at the National Research Centre (NRC), El Dokky, Giza Governorate. Identification of unknown compounds was based on comparing their retention time relative to those of the known compounds by matching spectral peaks available with Wiley 9 Mass Spectral Library ${ }^{46}$.

\section{Statistical analysis}

All data were expressed as mean \pm standard deviation of three replicates and submitted to variance analysis using SPSS-20.

\section{Declarations}


The authors thank Dr. Ahmed Abd Elkhalek (Lecturer of genetics, Mubarak city for scientific research, Alexandria) for his kind assistance and monitoring the data of Real time PCR experiment.

\section{Author contributions}

Nessma A. El Zawawy: Conceptualization, Methodology, Writing-Original Draft preparation, Writing Reviewing and Editing. Mahy M. Mona: Methodology, Writing- Reviewing and Editing.

\section{Conflict of Interest}

There are no conflicts to declare.

\section{Funding}

This research did not receive any specific grant from funding agencies in the public, commercial, or not -for-profit sectors.

\section{Data availability}

The datasets used and analyzed during this study are available from the corresponding author upon request.

\section{References}

1. Cilia, G. \& Fratini, F. Antimicrobial properties of terrestrial snail and slug mucus. Journal of complementary \& integrative medicine. 15(3), 1-10, https://doi.org/10.1515/jcim-2017-0168 (2018).

2. Smith, AM. \& Morin, MC. Biochemical differences between trail mucus and adhesive mucus from marsh periwinkle snails. Biol Bull. 203,338 - 346, DOI: 10.2307/1543576 (2002).

3. Benkendorff, K. et al. Are the traditional medical uses of muricidae molluscs substantiated by their pharmacological properties and bioactive compounds? Mar. Drugs. 13, 5237-5275, DOI: 10.3390/md13085237 (2015)

4. Ortega MP., García, M., Cánoves Escolano, A., Blasco, S. P. \& García, M. L. Tratamiento efectivo con un ungüento de glicina y prolina en un caso de úlceras recurrentes por déficit de prolidasa. Farm. Hospit. 30(5), 304-308, https://doi.org/10.1016/S1130-6343(06)73995-2 (2006).

5. Adikwu, M. \& U. Alozie, B. Application of snail mucin dispersed in detarium gum gel in wound healing. Scientific Research and Essay. 2, 195-198, (2007).

6. Dolashka-Angelova, P. et al. Immunological potential of Helix vulgaris and Rapana venosa hemocyanins. Immun. Invest. 37(8), 822-840 https://doi.org/10.1080/08820130802403366 (2008).

7. Schileyko, A. A. Treatise on recent terrestrial pulmonate molluscs. Part 13. Helicidae, Pleurodontidae, Polygyridae, Ammonitellidae, Oreohelicidae, Thysanophoridae. Ruthenica Suppl. 2, 1765-1906 (2006).

8. Ali, R. F. Morphological and Anatomical Characteristics of the Two Taxa Eremina desertorum desertorum (Forskål, 1775) and Eremina desertorum irregularis (Férussac, 1821) (Gastropoda: Helicidae) of the Northern Deserts of Egypt. Egypt. Acad. J. Biolog. Sci. 9 (1), 43- 54, DOI: 10.21608/EAJBSZ.2017.13456 (2017).

9. Kaltenbach H. Die individuelle, ökologische und geographische Variabilität der Wüstenschnecken Eremina desertorum, hasselquisti und zitteli. Arch. Naturgesch. N. F. 3, 383-404 (1934).

10. Kaltenbach H. Beitrag zur Kenntnis der Wüstenschnecken Eremina desertorum, kobelti und hasselquisti mit ihren individuellen, ökologischen und geographischen Rassen. Arch. Naturgesch. N. F. 11, 350-386. (1942). 
11. Ali, R. F., Neiber, M. T., Walther, F.\& Hausdorf, B. Morphological and genetic differentiation of Eremina desertorum (Gastropoda, Pulmonata, Helicidae) in Egypt. Zool. Scr. 45, 48-61 (2016).

12. Ali, SS., Morsy, R., El-Zawawy, NA., Fareed, M. \& Bedaiwy, MY. Synthesized zinc peroxide nanoparticles (ZnO2NPs): a novel antimicrobial, anti-elastase, antikeratinase, and anti-inflammatory approach toward polymicrobial burn wounds. Int. J. Nanomed. 12(12),6059-6073. (2017).

13. Abdel Rahman, AT. et al. Antimicrobial resistant bacteria among health care workers in intensive care units at Ain Shams University Hospitals. J. Egypt Soc. Parasitol., 40(1),71. (2010).

14. Saxena, N., Dadhich, D. \& Maheshwari, D. Aerobic bacterial isolates from burn wound infection patients and their antimicrobial susceptibility pattern in Kota, Rajasthan. J. Evol. Med. Dent. Sci.,23(2), 4156-4160. (2013).

15. Zlatko, K. Commentary Development of next-generation antimicrobial hydrogel dressing to combat burn wound infection. Bioscience Reports. 41, BSR20203404. (2021)

16. Olczyk, P., Mencner, L. \& Komosinska-Vassev, K. The role of the extracellular matrix components in cutaneous wound healing. Biomed. Res. Int. 2014,747584. (2014).

17. Khaheshi, I. et al. Loss of expression of TGF-ßs and their receptors in chronic skin lesions induced by sulfur mustard as compared with chronic contact dermatitis patients. BMC Dermatol. 11,2. (2011).

18. Bao, P. et al. The role of vascular endothelial growth factor in wound healing. J. Surg. Res. 153,347-58. (2009).

19. Negahdari, S., Galehdari, H., Kesmati, M., Rezaie, A. \& Shariati, G. Wound healing activity of extracts and formulations of Aloe vera, henna, Adiantum capillus-veneris, and myrrh on mouse dermal fibroblast cells. Int. J. Prev. Med. 8,18. (2017).

20. Kenawy. E. et al. Synthesis, characterization and biomedical applications of a novel Schiff base on methyl acrylate-functionalized chitosan bearing p-nitrobenzaldehyde groups. Int. J. Biol. Macromol. 122,833-843 (2019).

21. Greistorfer, S. et al. Snail mucus - glandular origin and composition in Helix pomatia. Zoology. 122, 126-138. (2017).

22. Newar, J. \& Ghatak, A. Studies on the Adhesive Property of Snail Adhesive Mucus. Langmuir. 31, 12155-12160 (2015).

23. Gentili V, Bortolotti D, Benedusi M, Alogna A, Fantinati A, Guiotto A, et al. (2020). HelixComplex snail mucus as a potential technology against $O 3$ induced skin damage. PLoS ONE 15(2), e0229613.

24. Ulagesan, S. \& Kim, H. J. Antibacterial and Antifungal Activities of Proteins Extracted from Seven Different Snails. Appl. Sci. 8,1362(2018).

25. El Zawawy, N. A., El-Shenody, R. A., Ali, S. S. \& El-Shetehy, M. 3 A novel study on the inhibitory efect of marine macroalgal extracts on hyphal growth and bioflm formation of candidemia isolates Scientific Reports. 10,9339 (2020).

26. Lopez Abarrategui, C. Screening of Antimicrobials from Caribbean Sea Animals and Isolation of Bactericidal Proteins from the Littoral Mollusk Cenchritis muricatus. Curr. Microbiol. 2012, 64, 501-505(2006).

27. Coppé JP., Kauser, K., Campisi, J. \& Beauséjour, CM. Secretion of vascular endothelial growth factor by primary human fibroblasts at senescence. J. Biol. Chem. 281:29568-29574 (2006).

28. Trapella C. et al. HelixComplex snail mucus exhibits pro-survival, proliferative and pro-migration effects on mammalian fibroblasts. Sci. Rep. 8 (1),17665(2018).

29. Strzelecka, M. \& Swiatek, P. 1,2,4-Triazoles as Important Antibacterial Agents Pharmaceuticals., 14, 224 (2021) 30. Huang, L. Phthalic Acid Esters: Natural Sources and Biological Activities Toxins. 13, 495. (2021). 
31. Viani, F. et al. Synthesis and anti-bacterial activity of a library of 1,2-benzisothiazol-3(2H)-one (BIT) derivatives amenable of crosslinking to polysaccharides. Tetrahedron. 73,1745-1761 (2017).

32. Yang, F. et al. Synthesis and biological evaluation of thiophene-based hydroxamate derivatives as HDACis with antitumor activities Future Med. Chem. 12(8), 655-672(2020).

33. Abdul Jalill, R. D. GC-MS analysis of calendula officinalis and cytotoxic effects of its flower crude extract on human epidermoid larynx carcinoma (HEP-2). WORLD JOURNAL OF PHARMACY AND PHARMACEUTICAL SCIENCES. 3(4), 237-275. (2014).

34. Meikle, P., Richards, GN.\& Yellowless, D. Structural investigations on the mucus from six species of coral. Mar. Biol. 99,187 - 193 (1988).

35. Sallam, A. A., El-Massry, S. A. \& Nasr, I. N. Chemical analysis of mucus from certain land snails under Egyptian conditions. Archives of Phytopathology and Plant Protection. 42(9),874 - 881 (2009).

36. Etim, L., Aleruchi, C. \& Obande, G. Antibacterial Properties of Snail Mucus on Bacteria Isolated from Patients with Wound Infection, British Microbiology Research Journal. 11(2), 1-9 (2016).

37. Schileyko, A. Treatise on recent terrestrial pulmonate molluscs. Ruthenica. 2.731-880. (2000).

38. Ali, S. et al. A new bioactive antimicrobial and antioxidant agent to combat multi-drug/ pan-drug resistant pathogens of wound burn infections, Journal of Traditional and Complementary Medicine.10,13-25(2019).

39. Mona, M. M., El-Zawawy, N. \& Atlam, A. Abundant ceiling spider in Tanta city (Egypt) with special reference to the antifungal effect of its web on healing human wounds and burns. Sylwan.160(7),44-57 (2017).

40. El Zawawy, A. N., El-Shenody, R. A., Ali, S. S. \& El-Shetehy, M. A novel study on the inhibitory efect of marine macroalgal extracts on hyphal growth and bioflm formation of candidemia isolates1. Scientific Reports 10, 9339. (2020).

41. Lauth, X. et al. Discovery and characterization of two isoforms of moronecidin, a novel antimicrobial peptide from hybrid striped bass. J. Biol. Chem. 277, 5030-5039. (2002).

42. Ali, S. S. et al. Pharmaceutical Potential of a Novel Chitosan Derivative Schiff Base with Special Reference to Antibacterial, Anti-Biofilm, Antioxidant, Anti- Inflammatory, Hemocompatibility and Cytotoxic Activities Pharm Res.36,5 (2019).

43. Skehan, P. et al. New colorimetric cytotoxicity assay for anticancer-drug screening. J. Natl. Cancer Inst. 82(13), 1107-1112. (1990).

44. Rao Bolla, S. In vitro wound healing potency of methanolic leaf extract of Aristolochia saccata is possibly mediated by its stimulatory effect on collagen-1 expression. Heliyon. 5(5), e0164(2019).

45. Mannan, A. U., Sharma, S., Ganesan, K. \& Total, R. N. A. (2009). Isolation from recalcitrant yeast cells. Anal. Biochem. 77(79), 389

46. Annegowda, H. V. et al. TLC-bioautography-guided isolation, HPTLC and GC-MS assisted analysis of bioactive of Piper betle leaf extract obtained from various extraction techniques: in vitro evaluation of phenolic content, antioxidant and antimicrobial activities. Food Anal. Methods. 6, 715-726. (2013).

\section{Figures}



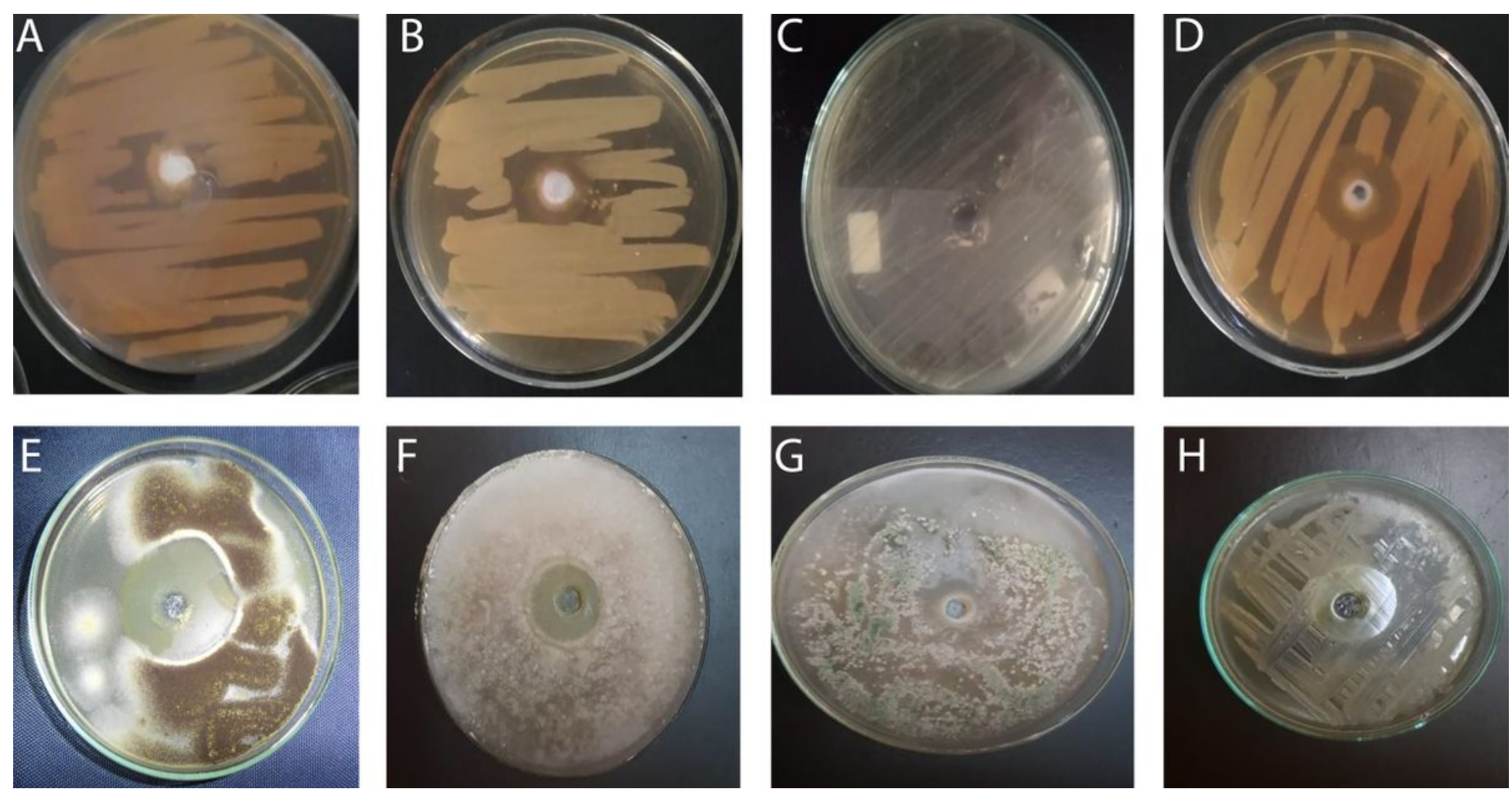

\section{Figure 1}

Antimicrobial activities of ME of E. desertorum by agar well diffusion method. A: PA-9; B: EC-3; C: KP-1; D: SA-17; E: AN-05; F: RS; G: TH; H: CA-11. 
$\mathbf{A}$

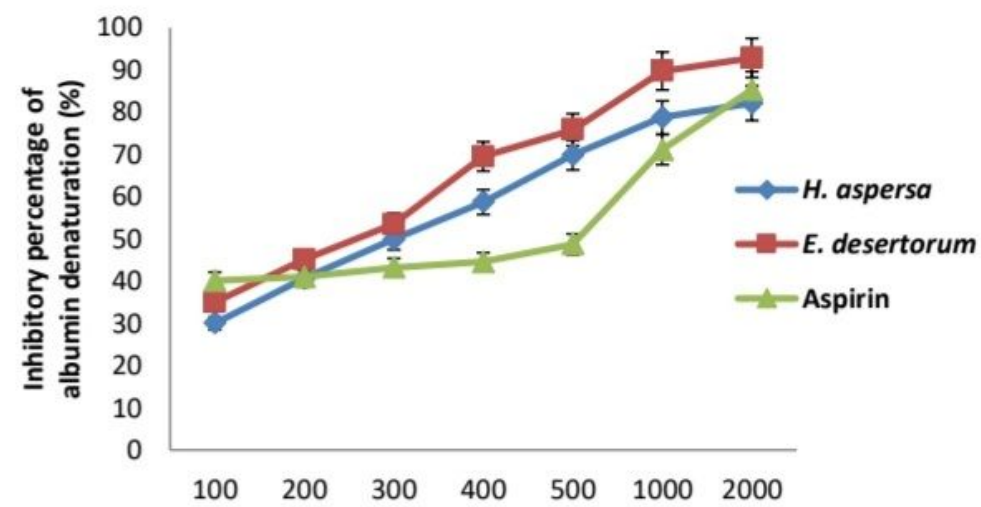

B

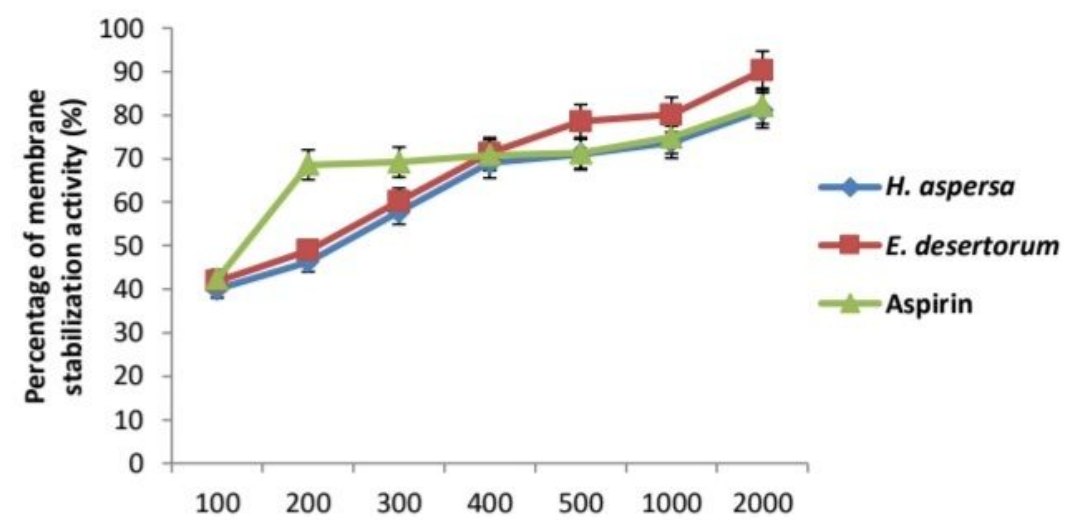

C

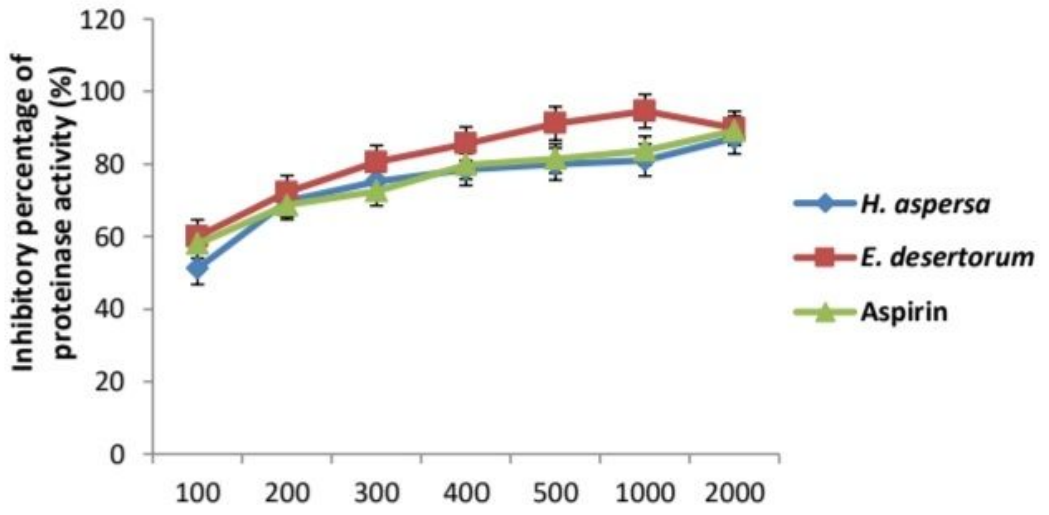

\section{Figure 2}

Anti-inflammatory activity of MEs of both snails compared to aspirin. 
A

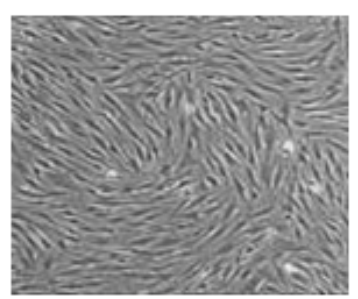

Untreated

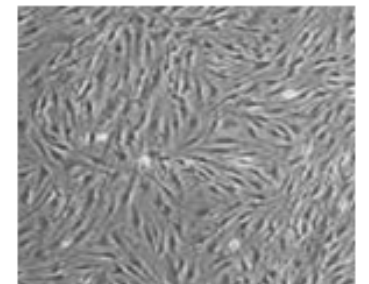

$300 \mu \mathrm{g} / \mathrm{ml}$ of

H. aspersa

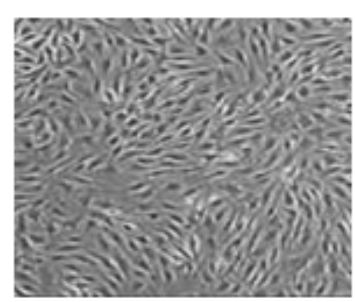

$300 \mu \mathrm{g} / \mathrm{ml}$ of

E. desertorum

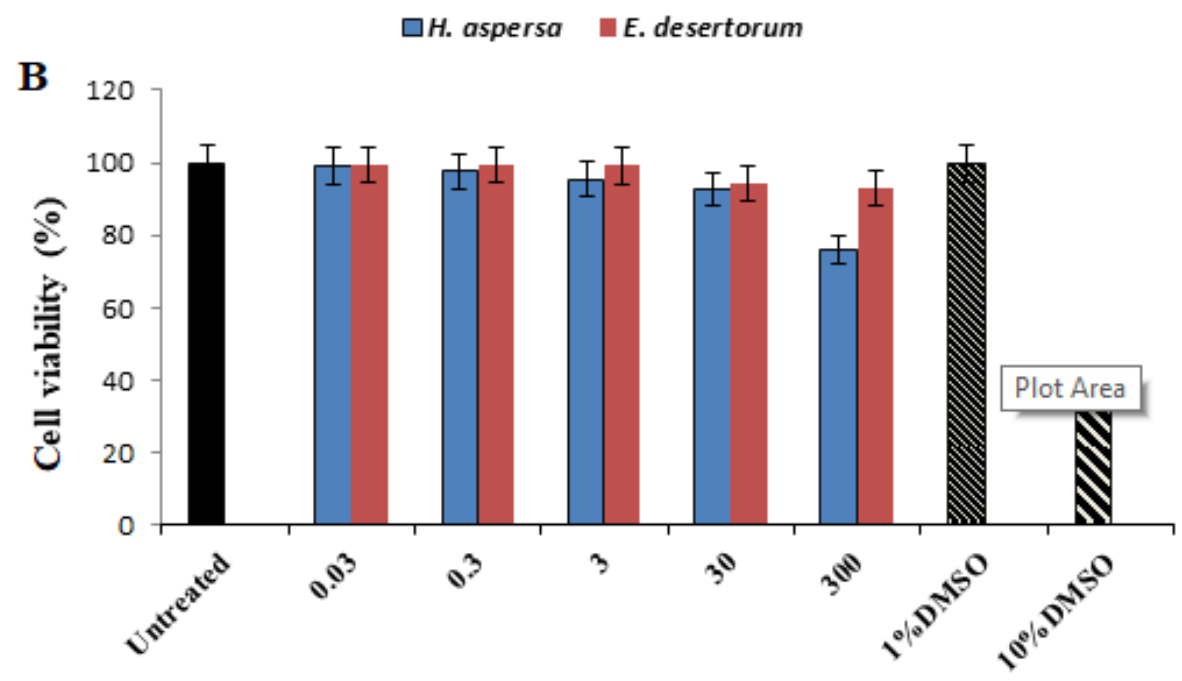

Figure 3

Cytotoxicity evaluation of MEs of both selected snails. HSF cells were exposed to $300 \mu \mathrm{g} / \mathrm{ml}$ of MEs of both selected snails and cell viability was examined by SRB assay. A) Representative images with magnification of (10X) taken by light microscopy of HSF cells untreated and treated with $300 \mu \mathrm{g} / \mathrm{ml}$ of both selected strains at 48 hrs. B) Cell viability was calculated at 24, 48 and 72 hrs compared to untreated cells (control), DMSO (10\%) and (1\%) were used as positive and vehicle controls of cell death, respectively. 


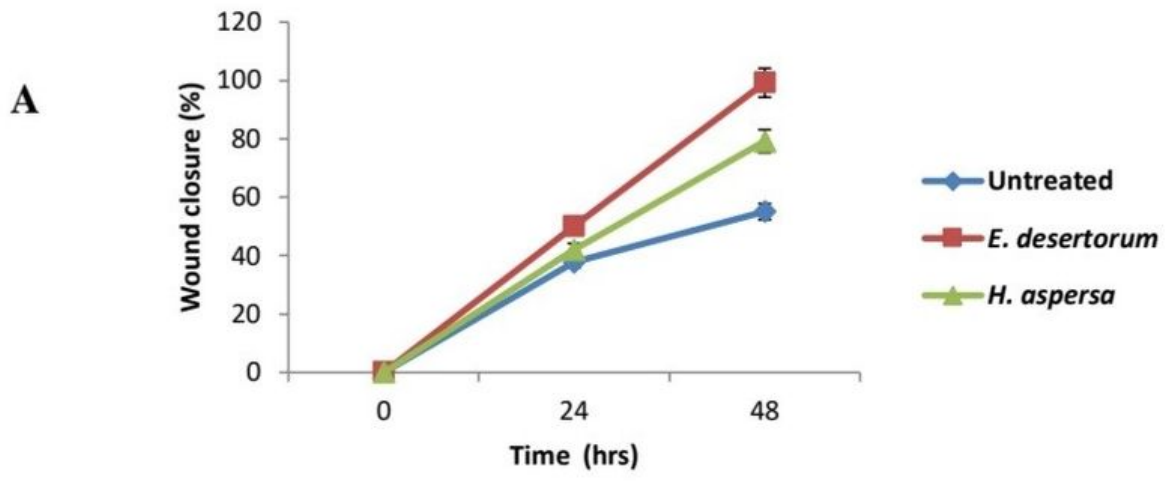

B
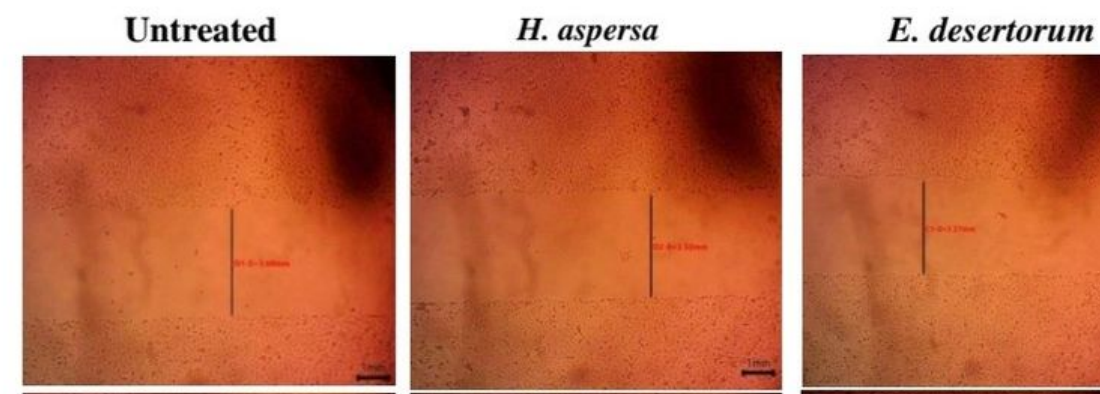

24
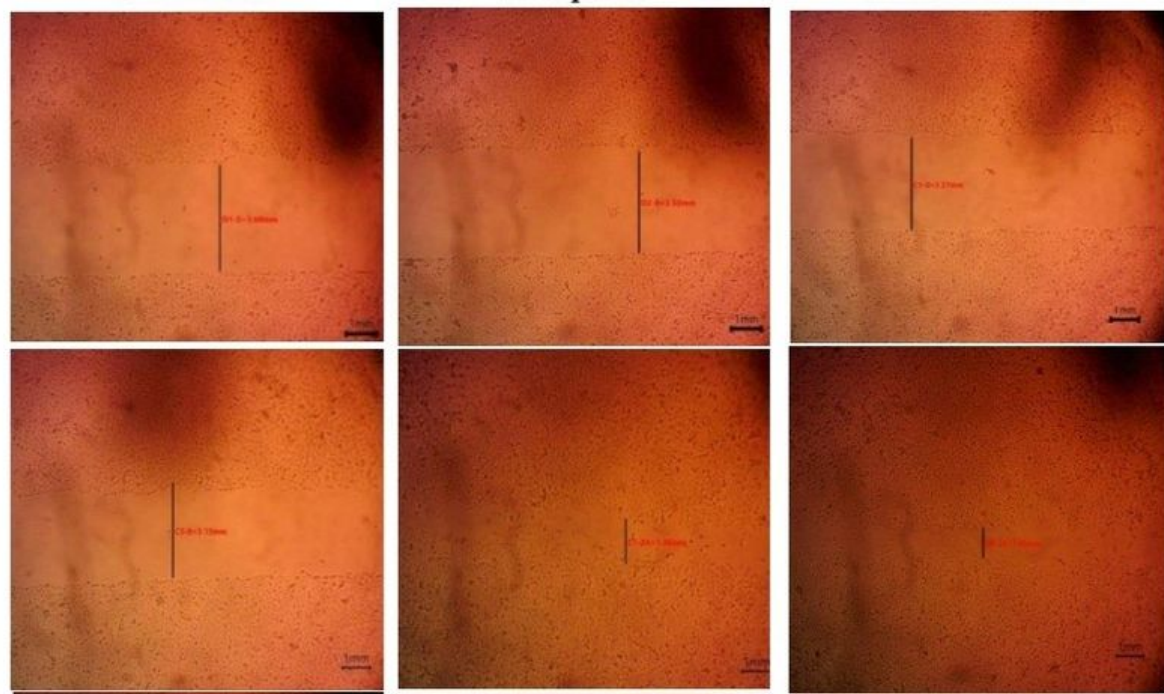

48

hrs
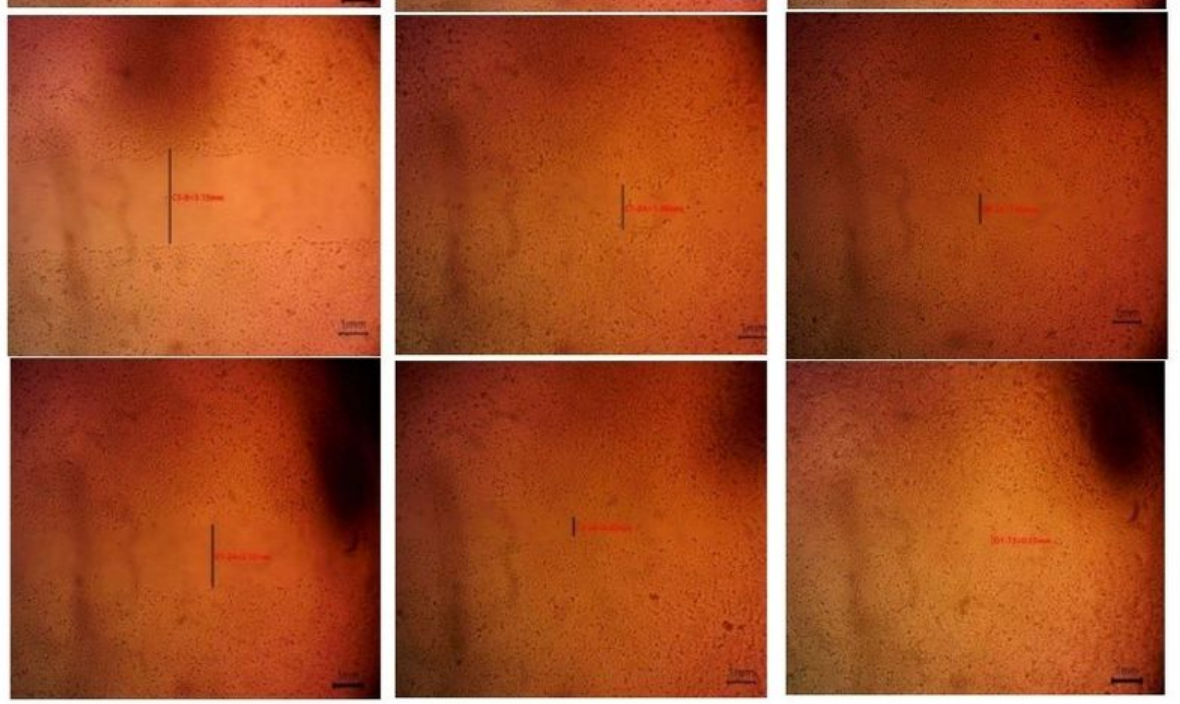

\section{Figure 4}

Scratch-wound healing assay. A) Percentage of wound closure at 0, 24, $48 \mathrm{hrs}$. in the absence and presence of MEs of both selected snails $(300 \mu \mathrm{g} / \mathrm{ml})$. B) Microscopical representative images for wound healing of MEs of both selected snails. 


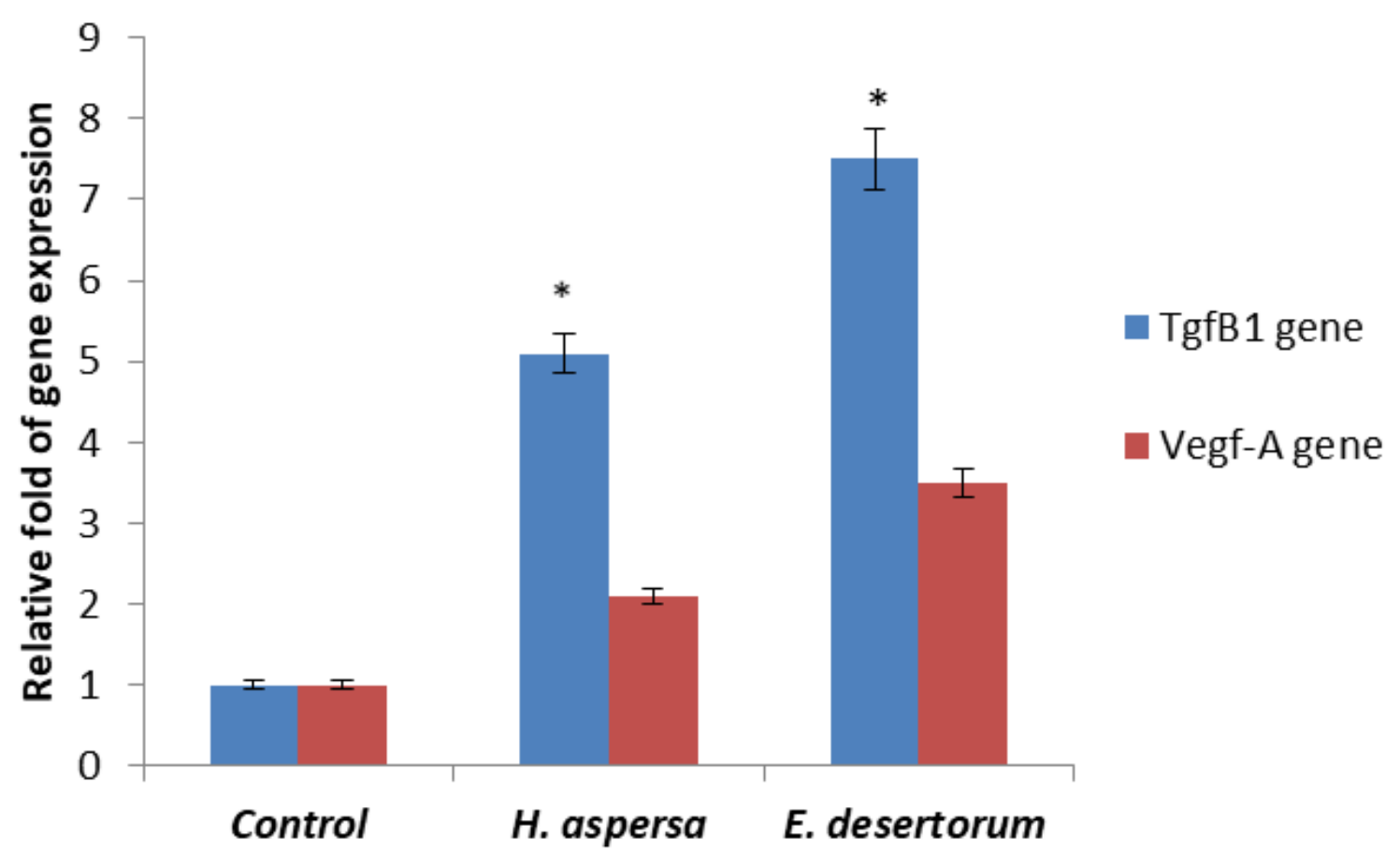

Figure 5

Effect of MEs of both snails $(300 \mu \mathrm{g} / \mathrm{ml})$ on the expression of Tgf $\beta 1$ and Vegf-A genes in HSF cells after $48 \mathrm{hrs}$. ${ }^{*} \mathrm{p}<0.05$

\section{Supplementary Files}

This is a list of supplementary files associated with this preprint. Click to download.

- Supplementmahy.docx 